\title{
Effects of Orthogonal Heat Treatment on Microstructure and Mechanical Properties of GN9 Ferritic/Martensitic steel
}

\section{Tingwei Ma}

Northeastern University

Xianchao Hao ( $\nabla$ xchao@imr.ac.cn )

Institute of Metal Research, Chinese Academy of Sciences https://orcid.org/0000-0001-6467-9807

Ping Wang

Northeastern University

\section{Original Article}

Keywords: GN9 Ferritic/Martensitic steel, Orthogonal design, M23C6 carbide, Ductile-to-brittle transition temperature

Posted Date: March 5th, 2021

DOI: https://doi.org/10.21203/rs.3.rs-273377/v1

License: (c) (i) This work is licensed under a Creative Commons Attribution 4.0 International License. Read Full License 


\section{Abstract}

Microstructure and mechanical properties of GN9 Ferritic/Martensitic steel for sodium-cooled fast reactors have been investigated through orthogonal design and analysis. Scanning electron microscopy (SEM), transmission electron microscopy (TEM), differential scanning calorimeter (DSC), tensile and impact tests were used to evaluate the heat treatment parameters on yield strength, elongation and ductile-to-brittle transition temperature (DBTT). The results indicate that the microstructures of GN9 steel after orthogonal heat treatments consist of tempered martensite, $M_{23} C_{6}, M X$ carbides and $M X$ carbonitrides. The average prior austenite grains increase and the lath width decreases with the austenitizing temperature increasing from $1000^{\circ} \mathrm{C}$ to $1080^{\circ} \mathrm{C}$. Tempering temperature is the most important factor that influences the dislocation evolution, yield strength and elongation compared with austenitizing temperature and cooling methods. Austenitizing temperature, tempering temperature and cooling methods show interactive effects on DBTT. Carbide morphology and distribution, which is influenced by austenitizing and tempering temperatures, is the critical microstructural factor that influences the Charpy impact energy and DBTT. Based on the orthogonal design and microstructural analysis, the optimal heat treatment of GN9 steel is austenitizing at $1000^{\circ} \mathrm{C}$ for $0.5 \mathrm{~h}$ followed by air cooling and tempering at $760{ }^{\circ} \mathrm{C}$ for $1.5 \mathrm{~h}$.

\section{Introduction}

Compared with austenitic stainless steels, $9-12 \% \mathrm{Cr}$ heat-resistant steels exhibit superior resistance to radiation-induced swelling [1], high thermal conductivity and low thermal expansion [2]. They also have good oxidation and corrosion resistance in liquid metals at elevated temperatures [3-4]. Hence, 9-12\% $\mathrm{Cr}$ steels are considered as one of the main candidate materials for core structures in Generation IV nuclear reactors [2,5]. From 1950's, three generations of heat-resistant steels have been manipulated in fossil power plants [6-7]. Modified 9Cr-1 Mo steel (commercialized as T91 steel) is the second generation heatresistant steel. It was modified from T9 (9Cr-1Mo) steel by adding $\mathrm{V}$, Nb, and $\mathrm{N}$ from 1970's and have been extensively used in fossil power plants [8] because of its high creep-rupture strength at $500-600{ }^{\circ} \mathrm{C}$. For employment in high-neutron irradiation environments, modified $9 \mathrm{Cr}-1$ Mo steel would become sensitive to an abrupt shift in ductile-to-brittle transition temperature (DBTT) towards high temperatures and a decrease in the upper shelf energy (USE) [9-11]. As a main candidate for wrapper applications in sodium-cooled fast reactors, the increase in the DBTT and the reduction in impact toughness is the most serious concern for application of modified $9 \mathrm{Cr}-1 \mathrm{Mo}$ steel. Lowering the DBTT and increasing the USE of $9-12 \% \mathrm{Cr}$ steels before irradiation is considered a useful method to reduce the increments of DBTT and reduction of USE [12]. Though irradiation conditions show some extent effects on the shift of DBTT [13], metallurgical conditions of $9-12 \% \mathrm{Cr}$ steels are considered the main influential factors. The reduction of inclusion content [14] or impurity elements [15] in ingots are effective to enhance impact toughness. The modifications of chemical composition $[5,16]$, microstructure [17-18] and heat treatment $[2,19-20]$ are also useful methods. 
Two important steps of heat treatments, i.e., austenitizing and tempering, are performed to modify the microstructure of modified $9 \mathrm{Cr}-1 \mathrm{Mo}$ steel. The main microstructural evolution during austenitizing is the dissolution of carbides or carbonitrides and the transformation of martensite by following cooling. Coarsened grain size and high level of $\delta$-ferrite should be avoided after austenitizing [21]. Microstructural evolution during tempering is complicated and involves the precipitation of carbides or carbonitrides, the modification of precipitate distribution and the annealing of dislocations. The heat treatment regime for modified $9 \mathrm{Cr}-1 \mathrm{Mo}$ steel recommended in literature [22-24] is austenitizing at $1040-1080{ }^{\circ} \mathrm{C}$ and tempering at $730-780^{\circ} \mathrm{C}$ followed by air cooling. The resulting microstructure is composed by lath martensite and the precipitates are $\mathrm{M}_{23} \mathrm{C}_{6}$ and $\mathrm{MX}$. Liu et al. [25] reported that the precipitation of $\mathrm{M}_{3} \mathrm{C}$ depends on the cooling rate though different austenitizing temperature and cooling methods. Jones et al. [26] found that the lath structure of air-cooled was clearer than that of water quenching after austenitizing of $9 \mathrm{Cr}-1 \mathrm{Mo}$ steel. Karthikeyan [19] and Raj [5] recommended grain refinement through a double austenitizing treatment and grain boundary engineering to overcome the reduction of impact toughness.

In addition to prior austenite grain size, heat treatments have effects on precipitate characteristics, martensite lath and packet size, and dislocation character. They all show some effects on impact toughness [27-28]. Though many studies of modified 9Cr-1 Mo steel have been carried out and focused on sole parameter of heat treatments [2,19-20], austenitizing, tempering and the cooling methods have interactive effects on microstructure evolution and the related mechanical properties. Hence, it deserves some further research to clarify the relationship between its complex microstructure [29] and heat treatment parameters and to enhance the impact toughness. Moreover, more strict requirements have been proposed with the developments of Generation IV nuclear reactors. Modified $9 \mathrm{Cr}-1 \mathrm{Mo}$ steel for application in new-generation sodium-cooled reactors should have high-tensile strength, moderate ductility under ambient and elevated temperatures and low DBTT and high impact toughness [30]. To separate their effects on yield strength, elongation and ductile-brittle transition temperature (DBTT), the orthogonal design method, is used in this paper. An optimal heat treatment is, therefore, put forward based on the experimental results.

\section{Materials And Experimental Procedures}

\subsection{Material and specimen preparation}

The GN9 Ferritic/Martensitic steel used in the present study was melted in a $50 \mathrm{~kg}$ vacuum induction furnace. The ingot was hot forged into $40 \mathrm{~mm}$-thick plates and then hot-rolled into $14 \mathrm{~mm}$-thick plates at $1050^{\circ} \mathrm{C}$. The chemical composition in weight percentage (wt.\%) of the experimental material is listed in Table 1. The impurity contents of $\mathrm{P}, \mathrm{O}$ and $\mathrm{S}$ are $0.009,0.003$ and $0.003 \%$, respectively. 
Table 1

Chemical compositions of GN9 steel (wt. \%)

\begin{tabular}{|lllllllllll|}
\hline $\boldsymbol{C}$ & $\boldsymbol{S i}$ & $\boldsymbol{C r}$ & $\mathbf{M o}$ & $\boldsymbol{V}$ & $\mathbf{N b}$ & $\boldsymbol{N}$ & $\boldsymbol{B}$ & $\mathbf{M n}$ & $\mathbf{N i}$ & $\mathbf{F e}$ \\
\hline 0.086 & 0.25 & 8.13 & 0.85 & 0.19 & 0.07 & 0.105 & 0.002 & 0.47 & 0.19 & Bal. \\
\hline
\end{tabular}

The critical transformation temperature was studied by differential scanning calorimeter (DSC). From DSC result, the phase transformation temperatures, i.e., $A_{c 1}, A_{c 3}$ and $T_{c}$ were determined to be 822,892 and $752{ }^{\circ} \mathrm{C}$, respectively. Based on the obtained critical temperatures and heat treatment parameters by Gutierrez [24], the austenitizing and tempering temperatures, as well as the following cooling method after austenitizing were chosen as orthogonal factors to design the orthogonal experiment, which are presented in Table 2. Through orthogonal experiment it can obtain the optimal influence factor and parameter of GN9 steel only by few experiments. Here, A, B and C in Table 2 stand for austenitizing temperature, tempering temperature and cooling method, respectively. $\mathrm{D}$ is error column. The holding time for austenitizing and tempering is $0.5 \mathrm{~h}$ and $1.5 \mathrm{~h}$, respectively. And the cooling method after tempering is air cooling.

\subsection{Microstructure and mechanical properties analysis}

A variety of techniques, including optical microscopy (OM: Axio Observer ZIm), scanning electron microscopy (SEM: Zeiss Ultra55) and transmission electron microscopy (TEM: JEOL 2100) were employed to characterize the microstructure of GN9 steel. The samples were mounted, polished and etched with a $35 \mathrm{~g} \mathrm{FeCl}_{3} / 10 \mathrm{ml} \mathrm{HCl} / 100 \mathrm{ml} \mathrm{H}_{2} \mathrm{O}$ solution for $\mathrm{OM}$ and $\mathrm{SEM}$ analysis. Five OM images were captured continuously at a magnification of 500 . for each sample and the prior austenite grain size was measured by the linear intercept method. To confirm the distribution and morphology of carbides, the samples were observed by SEM. Five images in different areas of each specimen were captured. About 100-200 carbide particles are counted and the average particle size was analyzed at a magnification of 30000. Thin foils for TEM analysis were prepared by using a twin-jet electro-polishing with a polishing electrolyte containing $10 \mathrm{ml}$ perchloric acid and $90 \mathrm{ml}$ ethanol under the conditions of $45 \mathrm{~mA}$, between 18 and $-25^{\circ} \mathrm{C}$, and $15 \mathrm{~cm}^{3} / \mathrm{s}$ flow rate. 
Table 2

Factors for orthogonal experiments in the present study

\begin{tabular}{|llll|}
\hline Experimental & A & B & C \\
\cline { 2 - 4 } No. & Austenitizing $/{ }^{\circ} \mathrm{C}$ & Tempering $^{\circ}{ }^{\circ} \mathrm{C}$ & Cooling method \\
\hline OW & 1000 & 650 & WQa \\
\hline OO & 1000 & 700 & OQb \\
\hline OA & 1000 & 760 & ACC \\
\hline 50 & 1050 & 650 & OQ \\
\hline $5 A$ & 1050 & 700 & AC \\
\hline $5 W$ & 1050 & 760 & WQ \\
\hline $8 A$ & 1080 & 650 & AC \\
\hline 8 W & 1080 & 700 & WQ \\
\hline 80 & 1080 & 760 & OQ \\
\hline Note: $a$-water quenching; $b$-oil quenching; $c$-air cooling \\
\hline
\end{tabular}

Standard Charpy V-notch specimens with dimension of $10 \mathrm{~mm} \cdot 10 \mathrm{~mm} \cdot 55 \mathrm{~mm}$ (length) were machined from the tempered specimens and used for impact tests. Three specimens for each impact test were taken from hot-rolled plates in T-L direction and the results were screened and averaged. Impact tests were conducted at temperatures between $-110^{\circ} \mathrm{C}$ and $23^{\circ} \mathrm{C}$. Boltzmann curves were used for analyzing the DBTT and upper shelf energy (USE).

Cylindrical tensile samples with $5 \mathrm{~mm}$ diameter and $25 \mathrm{~mm}$ gauge length were machined after tempering with gauge length parallel to rolling direction of the plate. Tensile tests were performed at room temperature and strain rate of $3 \cdot 10^{-3} \mathrm{~s}^{-1}$ on a hydraulic test system (Hitachi $100 \mathrm{kN}$ machine). Two specimens were prepared for tensile tests and the results were averaged.

\section{Results}

\subsection{Microstructure}

The microstructure of the hot-rolled specimen consists of deformed martensite and discrete carbides as shown in Fig. 1 (a). Austenization at $1050^{\circ} \mathrm{C}$ and $1080^{\circ} \mathrm{C}$ provide a structure of martensite and is marked by the absence of carbides, while austenization at $1000^{\circ} \mathrm{C}$ results in a structure of martensite and undissolved carbides as shown in Fig. 1 (b). 
The prior austenite grain size was calculated indifferent heat treatment conditions and the result is shown in Fig. 2. When the austenitizing temperature increases from $1000^{\circ} \mathrm{C}$ to $1080^{\circ} \mathrm{C}$, the average grain size varies from about $8 \mu \mathrm{m}$ to about $12 \mu \mathrm{m}$ and the prior austenite grains show sluggish growth tendency.

The microstructures of modified GN9 steel specimens in tempered conditions are analyzed using SEM and the results are shown in Fig. 3 . It can be seen that the amount of carbides increases with the increments of austenitizing and tempering temperatures. The carbide distribution is also influenced by heat treatment parameters. As shown in Fig. 3 (a), (d) and (g), carbides mainly distributed at prior austenite grain boundaries in samples tempered at $650^{\circ} \mathrm{C}$. Fine, discrete carbides precipitated at lath boundaries with the tempering temperature increasing from $650^{\circ} \mathrm{C}$ to $700^{\circ} \mathrm{C}$ in Fig. 3 (b), (e) and (h). Dense carbides distribute at boundaries of both prior austenite grains and lathes in samples tempered at $760^{\circ} \mathrm{C}$, Fig. 3 (c), (f) and (i). Figure 4 shows the TEM microstructure of GN9 steel after austenitizing at $1000^{\circ} \mathrm{C}$ followed by air cooling and tempering at $760^{\circ} \mathrm{C}$. A typical tempered martensite laths and dense dislocations can be obviously seen with blocky carbides in chains at grain boundaries. The electron diffraction patterns in Fig. 4(b) and (c) reveal that carbides in GN9 steel are $\mathrm{M}_{23} \mathrm{C}_{6}$ and $\mathrm{MX}$.

From Fig. 5, we can see that tempered martensite were found from $650^{\circ} \mathrm{C}$ to $760^{\circ} \mathrm{C}$, the dense of dislocation in martensite laths decrease with increase of tempered temperature at the same austenitizing temperature. Blocky carbides mainly distribute at prior austenite grain boundaries and martensite lath boundaries. And fine discrete carbides present in the laths. The martensite lath width is calculated based on the TEM observations and the result is shown in Fig. 2. Obviously, martensite lath width decreases from $220-250 \mathrm{~nm}$ to $180-190 \mathrm{~nm}$ with the austenitizing temperature increasing from $1000^{\circ} \mathrm{C}$ to 1080 ${ }^{\circ} \mathrm{C}$. Tempering show some influence on grain size and lath width, but its effect is less compared with austenitizition.

\subsection{Mechanical properties}

Tensile test results of GN9 steel specimens are listed in Table 3. It is evident that the yield strength and tensile strength decrease and the elongation increases when the tempering temperature increases from $650^{\circ} \mathrm{C}$ to $760^{\circ} \mathrm{C}$ at the same austenitizing temperature. The increments of austenitizing temperature show little influence on elongation.

Figure 6 shows the temperature dependence of the impact energy of GN9 steel specimens. The upper shelf energy (USE) is obtained through Boltzmann analysis. The temperature at impact energy of the half of USE in Fig. 6 is defined as DBTT and the results are listed in Table 3. We could see from Table 3 that the increment of tempering temperature could improve the USE, while austenitizing temperature shows less impact on the USE. The lower shelf energies decease with the increasing of yield strengths, but the upper shelf energies are independent of yield strength for the same tempering temperature. This trend is similar as that reported by Little [31]. 
Table 3

Tensile properties of GN9 steel specimens

\begin{tabular}{|lllllll|}
\hline Experimental No. & $R_{p 0.2}$ & $R_{m}$ & $E L$ & $R A$ & $D B T T$ & USE \\
& $M P a$ & $M P a$ & $\%$ & $\%$ & ${ }^{\circ} C$ & $J$ \\
\hline OW & 821.5 & 936 & 20.3 & 69.0 & -18 & 172 \\
\hline 00 & 674.5 & 802 & 21.5 & 70.0 & -50 & 182 \\
\hline OA & 523.5 & 710.5 & 26.5 & 68.0 & -58 & 216 \\
\hline 50 & 861.5 & 996.5 & 19.5 & 63.5 & 3 & 155 \\
\hline 5A & 723 & 845.5 & 20.3 & 66.0 & -28 & 192 \\
\hline 5W & 517 & 689.5 & 23.0 & 71.5 & -40 & 203 \\
\hline 8W & 849 & 971 & 20.0 & 67.0 & -26 & 162 \\
\hline 80 & 755 & 866 & 20.0 & 71.0 & -27 & 111 \\
\hline Note: $\mathrm{R}_{\mathrm{p} 0.2 \text {-yield strength, } \mathrm{R}_{\mathrm{m}} \text {-tensile strength, EL-elongation, RA-reduction of area }}$ \\
\hline
\end{tabular}

\subsection{Orthogonal design analysis}

The influence of heat treatment parameters on yield strength, elongation and DBTT is analyzed by orthogonal design methods and the related factors and $R$ [32]. is the mathematic average value of any column on level number $i(i=1,2,3)$. for factor $j(j=\mathrm{A}, \mathrm{B}, \mathrm{C})$ is calculated by Eq. (1). $R$ is a value of subtraction between the maximum and the minimum of in the same factor. $R$ for factor $j$ is calculated by Eq. (2). The average values and $R$ value of the yield strength $\left(\mathrm{R}_{\mathrm{p} 0.2}\right)$, elongation (EL) and impact toughness (DBTT) for each factor at different levels are depicted in Tables 4, 5 and 6 and Fig. 7.

$R$ manifests the relative influence on the objective functions. The higher the $R$, the stronger the influence of factor. Because $R$ is subtraction between the maximum and the minimum in the same factor, it can be analyzed intuitively by. The level of factor is important if is the maximum. Take the yield strength for example, is the maximum in the factor of austenitizing temperature in Table 4, it is concluded that normalization at $1080^{\circ} \mathrm{C}$ is a more important level than that at $1000^{\circ} \mathrm{C}$ or $1050^{\circ} \mathrm{C}$. In terms of , tempering at $650^{\circ} \mathrm{C}$ is a more important level than that at $700^{\circ} \mathrm{C}$ or $760^{\circ} \mathrm{C}$. For analysis, $\mathrm{OQ}$ is a more 
important level than WQ and AC. Analysis for EL and DBTT is performed in the same manner. As shown in Tables 5 and 6 , austenitizing at $1000^{\circ} \mathrm{C}$, tempering at $760^{\circ} \mathrm{C}$ and $\mathrm{AC}$ are important levels for $\mathrm{EL}$, while austenitizing at $1000^{\circ} \mathrm{C}$, tempering at $760^{\circ} \mathrm{C}$ and $\mathrm{AC}$ are important levels for DBTT.

Table 4

Orthogonal design analysis of yield strength $\left(\mathrm{R}_{\mathrm{p} 0.2}\right)$

\begin{tabular}{|llllllllll|}
\hline Source & & & & $R$ & $f$ & $S$ & $V$ & $F$ \\
\hline Austenitizing & 673.2 & 700.5 & 728.2 & 55 & 2 & 4537.6 & 2268.8 & 2.4 \\
\hline Tempering & 844 & 717.5 & 540.3 & 303.7 & 2 & 139603.7 & 69801.9 & 72.8 \\
\hline Cooling method & 697.8 & 705.5 & 698.5 & 7.7 & 2 & 108.2 & 54.1 & 0.1 \\
\hline Error & & & & & 2 & 1918.4 & 959.2 & \\
\hline Total & & & & & 8 & 146167.9 & $\mathrm{~F}_{0.05}(2,2)=19.0$ \\
\hline
\end{tabular}

For analyzing the effect of heat treatment factors on the material mechanical properties and finding out the optimum heat treatment regime, the analysis of variance (ANOVA) method was used on the basis of the degree of freedom $(f)$, the sum of squares $(S)$, variance $(V)$, and $F$-value. In these parameters, the difference between the values at different levels of each factor represents the relative influence degree [33]. The larger the difference, the stronger the influence [34]. The formulae applied in the present study are defined in Eqs. (3)-(7). 
where, $m$ is the number of factors, $n$ is the experiment number of each factor, $V_{\mathrm{e}}$ is the variance of error.

It is evident that tempering temperature is a significant factor on the $R_{p 0.2}$ at a $95 \%$ confidence limit through F-test results in Table 4. So the most important influential factor on $\mathrm{R}_{\mathrm{p} 0.2}$ is the tempering temperature. Austenitizing temperature and cooling method play negligible roles, which is consistent with the results based on $R$ value analysis.

As shown in Table 5, $F$-value for tempering temperature is 50.4 , which is more than $\mathrm{F}_{0.05}(2,2)=19.0$. Hence, tempering temperature play as more important role on the $E L$ at a $95 \%$ confidence compared with austenitizing temperature and cooling method. The relative influence order is tempering temperature, austenitizing temperature and cooling method, which is the same as that on $\mathrm{R}_{\mathrm{p} 0.2}$. However, austenitizing shows some extent influence on the EL of GN9 steel specimens.

Table 5

Orthogonal design analysis of elongation (EL)

\begin{tabular}{|lllllllll|}
\hline Source & & & & $\boldsymbol{R}$ & $\boldsymbol{f}$ & $\boldsymbol{S}$ & $\boldsymbol{V}$ & $\boldsymbol{F}$ \\
\hline Austenitizing & 22.8 & 20.9 & 21.2 & 1.9 & 2 & 6.0 & 3.0 & 8.9 \\
\hline Tempering & 19.9 & 20.6 & 24.3 & 4.4 & 2 & 33.7 & 16.9 & 50.4 \\
\hline Cooling method & 21.1 & 21.5 & 22.3 & 1.2 & 2 & 2.1 & 1.1 & 3.2 \\
\hline Error & & & & & 2 & 0.7 & 0.3 & \\
\hline Total & & & & & 8 & 42.5 & $F_{0.05}(2,2)=19.0$ \\
\hline
\end{tabular}

From the $F$ analysis in Table 6, it is evident that the relative influence order of heat treatment parameters on Charpy impact toughness (DBTT) is: tempering temperature, austenitizing temperature and cooling method. However, $F$-values for three heat treatment factors is lower than $F_{0.05}(2,2)=19.0$. Fan et al. [33] suggested that the heat treatment parameters had a slight effect on the impact toughness of $1 \mathrm{Cr} 12 \mathrm{NiMo}$ steel. The present work shows the similar results for GN9 steel.

The influence of three factors was re-evaluated from Fig. 7. From Fig. 7(a) and (b), it is evident found that the difference between the $R_{p 0.2}$ and $E L$ values at different levels of tempering temperature is more notable than that of the other two factors. From Fig. 7(c), the difference between the DBTT values at different levels of tempering temperature is the most notable, which shows the similar trend as that by $R$ test in Table 6. However, the fluctuation of three factors for DBTT does not keep a monotone decreasing or increasing manner in Fig. 7(c). It could be concluded that all three factors show some interactive effects on DBTT of GN9 steel. 
Table 6

Orthogonal design analysis of ductile-brittle transition temperature (DBTT)

\begin{tabular}{|lcccccccc|}
\hline Source & & & & $\boldsymbol{R}$ & $\boldsymbol{f}$ & $\boldsymbol{S}$ & $\boldsymbol{V}$ & $\boldsymbol{F}$ \\
\hline Austenitizing & -41.6 & -21.9 & -22.2 & 19.7 & 2 & 764.5 & 382.3 & 1.5 \\
\hline Tempering & -13.7 & -34.7 & -37.4 & 23.7 & 2 & 1010 & 505 & 2.0 \\
\hline Cooling method & -28.4 & -20.4 & -37 & 16.6 & 2 & 413.5 & 206.8 & 0.8 \\
\hline Error & & & & & 2 & 515.8 & 257.9 & \\
\hline Total & & & & & 8 & 2703.9 & $F_{0.05}(2,2)=19.0$ \\
\hline
\end{tabular}

\section{Discussion}

\subsection{Heat treatment on tensile properties}

The strengthening mechanisms of $9-12 \% \mathrm{Cr}$ steels is classified into four categories, i.e., martensite transformation hardening, solution hardening, particle hardening and dislocation hardening. Martensite transformation hardening and solution hardening are the main reasons for the favorable effect on yield and tensile strength of increasing austenitizing temperature. As mentioned in Sect. 3, the dissolution of carbides enhances the saturation of $\mathrm{Cr}$, Mo and $\mathrm{C}$ in the matrix with the increasing of austenitizing temperature, which contributes to the solution hardening. Carbide dissolution also promotes the martensite transformation during austenization because the supersaturation of $\mathrm{C}$ causes an increase in the tetragonality of martensite [33]. As shown in Fig. 2, the increasing austenitizing temperature show some favorable effects on reducing the lath width of GN9 steel, which also promote the increasing of room temperature strength.

During tempering, supersacturated $C$ migrates from quenched martensite and forms $M_{23} C_{6}$ carbides and $M X$. The increment of tempering temperature promotes the precipitation of carbides, which lowers the hardening effects of martensite. The main microstructure of tempering specimens as shown in Fig. 4 consists of tempered martensite. From Fig. 5 , it is evident that the dense of dislocation decreases with increasing tempering temperature at the same austenitizing temperature. On the other hand, $\mathrm{M}_{23} \mathrm{C}_{6}$ carbides are considered as the main obstacle for boundary movements and contribute to particle hardening. MX can pin the dislocation and improve the yield strength. However, the enhancement of carbide evolution to the strength seems limited compared with the reducing effects from the transformation of tempered martensite and the decreasing dislocation dense.

As shown in Table 3, the elongation of GN9 steel specimens after tempering at $650^{\circ} \mathrm{C}$ or $700{ }^{\circ} \mathrm{C}$ is about $20 \%$ with the results increasing to $23-26.5 \%$ after tempering at $760{ }^{\circ} \mathrm{C}$. Compared with tempering 
temperature, the variation of austenitizing conditions has little influence on elongation. The main microstructural factors for elongation could be determined as dislocation dense through Fig. 5.

\subsection{Microstructural aspects on impact toughness}

The interactive effects between heat treatment parameters on impact toughness of GN9 steel should be attributes to their effects on the microstructural evolution. As for $9-12 \% \mathrm{Cr}$ FMS $[2,5,16-20]$, the reported influential factors on DBTT could be listed as follows: prior austenite grains, lath width, carbide morphology and distribution, dislocation density.

The beneficial effect of fine grain in reducing the DBTT and increasing the USE is well known for ferritic/martensitic steels [35-36]. As shown in Fig. 2 the average prior austenite grain sizes vary within narrow limits, i.e., 8-12 $\mu \mathrm{m}$. It could then be concluded that the prior austenite grain size is not the main factor for the variation of DBTT in GN9 steel specimens. Though lath widths decrease with the increasing austenitizing temperature, the upper shelf energy and DBTT are not improved as shown in Table 3.

As is known [37], inhomogeneous deformation occurs in interfaces between carbides and martensite matrix and dislocations concentrate around carbide particles under high strain rate (approximately $10^{3} \mathrm{~s}^{-}$ 1 [38]) during Charpy impact testing. With the increasing of deformation, the accumulated dislocations and local deformation make the cohesion of interfaces weaken and microcracks form. The increasing amount of carbide sprovokes the microcrack formation and the subsequent propagation. However, the morphology and particle dimensions are the main factor which determines the propagation of microcracks [18, 39-40]. As proposed by Rolfe [41], the impact energy $\left(K_{V}\right)$, fracture strength $\left(K_{\mathrm{Ic}}\right)$ and yield strength $\left(R_{P 0.2}\right)$ could be expressed by Eq. (8). Habu and Rosenfiela [42] propose that the displacement $(\delta)$ of a microcrack tip equals to the adjacent distance $(\lambda)$ of particles which make a microcrack propagates. The displacement $(\delta)$ and distance $(\lambda)$ could be depicted by Eqs. (9) and (10), respectively. 
where $v$ is a constant and equals to about $0.3, E$ is Yong's modulus, $f$ is the volume fraction of carbides, $r$ is the average carbide size. The combination of Eqs. (8), (9) and (10) generates:

11

We could see from Eq. (11) that the Charpy impact energy is proportional to the particle size and inverse to the volume fraction of carbides. Compared with tempering at $650^{\circ} \mathrm{C}$ and $700^{\circ} \mathrm{C}$, the carbide sizes at grain boundaries and lath boundaries increase obviously in specimens after tempering at $760^{\circ} \mathrm{C}$. And the proposed mechanism of carbides on impact toughness is illustrated in Figure 8. With the microcrack propagating along boundaries to the front of carbide, the crack tends to deviate along the interface of carbide and matrix instead of the cracking of carbides. The deviation makes the propagating length of microcracks increase. Energies for the microcrack propagation, therefore, increase, which represents the increasing absorbed energies during Charpy impact testing. From Figure 3 and 5 , the amount of $\mathrm{M}_{23} \mathrm{C}_{6}$ in specimens tempered at $650^{\circ} \mathrm{C}$ is low and the particle size is smaller, which lowers the upper shelf energy and raises the DBTT of steel specimens. With the tempering temperature up to $760^{\circ} \mathrm{C}$, the increments of carbide density and particle sizes in GN9 steel specimens show favorable effects on impact performance as shown in Table 3 and Figure 8.

Dislocation density has effects on Charpy impact toughness through influencing the yield strength. As suggested by Eq. (8), the higher the yield strength $\left(R_{p 0.2}\right)$, the lower the impact absorbed energy. With the decreasing test temperature from room temperature to $-110^{\circ} \mathrm{C}$, the increments of yield strength is more significant than that of fracture strength $\left(K_{\mathrm{IC}}\right)$, which makes the DBTT increases. However, the fluctuation of DBTT does not keep a monotone decreasing or increasing manner in Table 3 for different heat treatment conditions. Dislocation evolution during heat treatments, therefore, might not be acritical factor that has the same effects as $\mathrm{M}_{23} \mathrm{C}_{6}$ as mentioned above.

\subsection{Optimal heat treatment regime}

As discussed above, the cooling method is not a significant factor for tensile properties of GN9 steel. From Fig. 7, the optimum values of yield strength $\left(\mathrm{R}_{\mathrm{p} 0.2}\right)$ and elongation $(E L)$ are obtained at the level of parameter C2 (oil quench) and C3 (air cooling), respectively. The Charpy impact toughness (DBTT) is minimum at the level of parameter C3 (air cooling). The optimal cooling method for GN9 steel is recommended to be air cooling after austenization.

From Fig. 7, we could see that the highest yield strength, the maximum elongation and the lowest DBTT could be obtained when the austenitizing temperatures were chosen as $A 3\left(1080^{\circ} \mathrm{C}\right), \mathrm{A} 1\left(1000^{\circ} \mathrm{C}\right)$ and $\mathrm{A} 1\left(1000^{\circ} \mathrm{C}\right)$, respectively. Though not be dissolved completely in the temperature range of $1000-1080$ ${ }^{\circ} \mathrm{C}$, carbides or carbonitrides are used to pin grain boundaries and decreasing the grain size. The undissolved $\mathrm{M}_{23} \mathrm{C}_{6}$ particles have little effect on tensile and impact properties of GN9 steel from Table 3 . MX particles can pin the dislocation and hinder the dislocation movie, which enhance the strength of GN9 
steel. Hence, the optimal austenitizing temperature is recommended to be lowered from $1050{ }^{\circ} \mathrm{C}[22-24]$ to $1000^{\circ} \mathrm{C}$.

From the analysis of Table 4, Table 5 and Fig. 7, the value of $R_{p 0.2}$ decreased, while the value of EL increased with the increasing of tempering temperature. For getting good material properties on $R_{p 0.2}$ and $\mathrm{EL}$, tempering temperature can be chosen $\mathrm{B} 1\left(650^{\circ} \mathrm{C}\right)$ and $\mathrm{B} 3\left(760^{\circ} \mathrm{C}\right)$, respectively. The value of $\mathrm{R}_{\mathrm{p} 0.2}$ is 523.5 MPa when GN9 steel is temporized at $760^{\circ} \mathrm{C}$, which is sufficient to meet the demand of application $\left(R_{\mathrm{p} 0.2} \geq 490 \mathrm{MPa}\right)$. The value of DBTT is fittest when the tempering temperature was set at $\mathrm{B} 3\left(760^{\circ} \mathrm{C}\right)$

from the aspect of microstructure examination. In order to achieve optimum combination of $R_{p 0.2}, E L$ and DBTT, tempering temperature is chosen as $760^{\circ} \mathrm{C}$.

Based on above analysis, the optimal heat treatment regime is austenitizing at $1000{ }^{\circ} \mathrm{C}$ for $0.5 \mathrm{~h}$, followed by air cooling, and tempering at $760^{\circ} \mathrm{C}$ for $1.5 \mathrm{~h}$, followed by air cooling to room temperature.

\section{Conclusions}

The effect of heat treatment on the microstructure and mechanical properties of GN9 steel has been studied. The results obtained as follows:

(1) The microstructure of GN9 steel after orthogonal heat treatments consists of tempered martensite. The main precipitate is $\mathrm{M}_{23} \mathrm{C}_{6}$ carbides and $\mathrm{MX}$ carbonitrides. The distribution, morphology and amount of $\mathrm{M}_{23} \mathrm{C}_{6}$ are influenced by parameters of austenitizing and tempering treatments.

(2) The average prior austenite grain show sluggish growth tendency during austenization. The lath width decreases from $220-250 \mathrm{~nm}$ after austenization at $1000^{\circ} \mathrm{C}$ to $180-190 \mathrm{~nm}$ after austenization at 1080 ${ }^{\circ} \mathrm{C}$.

(3) With the increments of tempering temperature, dislocation density decreases. Austenitizing temperature and cooling methods have less influence on the dislocation evolution.

(4) Tempering temperature is the most important factor that influences the yield strength and elongation compared with austenitizing temperature and cooling methods. Austenitizing temperature, tempering temperature and cooling methods show interactive effects on impact toughness of GN9 steel from orthogonal design and analysis.

(5) Carbide morphology and distribution is the critical microstructural factor that influences the Charpy impact energy and DBTT of GN9 steel. Dense $\mathrm{M}_{23} \mathrm{C}_{6}$ carbides in discrete morphology could enhance the upper shelf energy and decrease the DBTT, while specimens with scarce, discrete and fine carbides at grain boundaries exhibit low shelf upper energy and high DBTT. The influence of prior austenite grains, lath width and dislocation density is not significant in the present study. 
(6) Based on the orthogonal design and microstructural analysis, the optimal heat treatment of GN9 steel is proposed as follows: austenitizing at $1000^{\circ} \mathrm{C}$ for $0.5 \mathrm{~h}$ followed by air cooling and tempering at $760^{\circ} \mathrm{C}$ for $1.5 \mathrm{~h}$.

\section{Declarations}

\section{Acknowledgements}

The authors would like to thank Mrs. Wenjun Li and Dr. Jinming Liu for their assistance on SEM and TEM tests and the discussion of results.

\section{Funding}

Supported by the Natural Science Foundation Guidance Plan of Liaoning Province (No. 2019-ZD-0362).

\section{Availability of data and materials}

The datasets supporting the conclusions of this article are included within the article.

\section{Authors' contributions}

The author' contributions are as follows: Ting-Wei Ma was in charge of the whole trial; Ting-Wei Ma and Xian-Chao Hao wrote the manuscript; Ping Wang assisted with sampling and laboratory analyses.

\section{Competing interests}

The authors declare no competing financial interests.

\section{Consent for publication}

Not applicable

\section{Ethics approval and consent to participate}

Not applicable

\section{References}

[1] Schaefer, A. O. Symposium on structural materials for service at elevated temperatures in nuclear power generation, American Society of Mechanical Engineering winter annual meeting, Houston, USA, November 30-Desember 3, 1975: 375-385.

[2] A Chatterjee, D Chakrabarti, A Moitra, et al. Effect of normalization temperatures on ductile-brittle transition temperature of a modified $9 \mathrm{Cr}-1$ Mo steel. Materials Science and Engneering: A, 2014, A618: 219-231. 
[3] R L Klueh, A T Nelson. Ferritic/martensitic steels for next-generation reactors. Journal of Nuclear Materials, 2007, 371: 37-52.

[4] B N Singh, J H Evans. Significant differences in defect accumulation behaviour between fcc and bcc crystals under cascade damage conditions. Journal of Nuclear Materials, 1995,226: 277-285.

[5] B Raj, S Saroja, K Laha, et al. Methods to overcome embrittlement problem in 9Cr-1Mo ferritic steel and its weldment. Journal of Materials Science, 2009, 44: 2239-2246.

[6] F Masuyama. History of power plants and progress in heat resistant steels. ISIJ International, 2001, 41: 612-625.

[7] R L Klueh. Elevated emperature ferrtic and martensitic steels and their application to future nuclear reactors. Internatonal Materials Reviews, 2005, 50: 287-310.

[8] R Viswanathan, W Bakker. Materials for ultrasupercritical coal power plants-boiler materials: Part 1. Journal of Materials Engineering and Performance, 2001, 10: 81-95.

[9] R L Klueh, D J Alexander. Impact Behavior of 9Cr-1MoVNb and 12Cr-1MoVW steels Irradiated in HFIR. Journal of Nuclear Materials, 1991, 179-181: 733-736.

[10] C Wassilew, K Ehrlich. Effect of neutron irradiation on the dynamic fracture toughness behavior of the $12 \%$ Cr steel MANET-I investigated using subsize V-notch specimens. Journal of Nuclear Materials, 1992, 191-194: 850-854.

[11] Y Dai, P Marmy. Charpy impact tests on martensitic/ferritic steels after irradiation in SINQ target-3. Journal of Nuclear Materials, 2005, 343(1-3): 247-252.

[12] R L Klueh, J J Kai, D J Alexander. Microstructure-mechanical properties correlation of irradiated conventional and reduced-activation martensitic steels. Journal of Nuclear Materials, 1995, 225: 175-186.

[13] D S Gelles. Microstructural examination of commercial ferritic alloys at $200 \mathrm{dpa}$. Journal of Nuclear Materials, 1996, 233(1): 293-298.

[14] C Y Yang, Y K Luam, D Z Li, et al.. Effects of rare earth elements on inclusions and impact toughness of high-carbon chromium bearing steel. Journal of Materials Science Technology, 2019, 35: 1298-1308.

[15] Q Y Huang. Development status of CLAM steel for fusion application. Journal of Nuclear Materials, 2014, 455: 649-654.

[16] P Jung, H Klein. Segregation in DIN 1.4914 martensitic stainless steel under proton irradiation. Journal of Nuclear Materials, 1991, 182: 1-5.

[17] T. Watanabe, S. Tsurekawa. Toughening of brittle materials by grain boundary engineering. Materials Science and Engneering: A, 2004, 387-389: 447-455. 
[18] S.A. Bashu, K. Singh, M.S. Rawat. Effect of heat treatment on mechanical properties and fracture behaviour of a 12CrMoV steel. Materials Science and Engneering: A, 1990, 127: 7-15.

[19] T. Karthikeyan, V.T. Paul, S. Saroja, A. Moitra, G. Sasikala, M. Vijayalakshmi. Grain refinement to improve impact toughness in $9 \mathrm{Cr}-1 \mathrm{Mo}$ steel through a double austenitization treatment. Journal of Nuclear Materials, 2011, 419: 256-262.

[20] A. Chatterjee, A. Moitra, A.K. Bhaduri, D. Chakrabarti, R. Mitra, Effect of Heat Treatment on DuctileBrittle Transition Behaviour of 9Cr-1 Mo Steel. Procedia Engineering, 2014, 86: 287-294.

[21] J.B. Zhang, F. Liu, D. Fan, Z.Y. Zhen. Effect of Heat Treatment on Delta-ferritie and Impact Toughness of P91 Heat-resistant Steel. Transactions of Materials and Heat Treatment, 2017, 38: 108-113. (in Chinese)

[22] Chinese National Standard Committee. GB/T 5310-2008, Seamless steel tubes and pipes for high pressure boiler. Beijing: Standards Press of China, 2008. (in Chinese)

[23] R L Klueh., N Hashimoto, R F Buck et al. A potential new ferritic/martensitic steel for fusion applications. Journal of Nuclear Materials, 2000,283-287:697-701.

[24] N.Z. Gutiérrez, H. De Cicco, J. Marrero, C.A. Danón, M.I. Luppo. Evolution of precipitated phases during prolonged tempering in a $9 \% \mathrm{Cr} 1 \% \mathrm{MoVNb}$ ferritic-martensitic steel: Influence on creep performance. Materials Science and Engneering: A, 2011, 528: 4019-4029.

[25] C.X. Liu, D.T. Zhang, Y.C. Liu, Q. Wang, Z.S. Yan, Investigation on the precipitation behavior of M3C phase in T91 ferritic steels. Nuclear Engineering and Design, 2011, 241: 2411-2415.

[26] W.B. Jones, C.R. Hills, D.H. Polonis, Microstructural evolution of modified 9Cr-1Mo steel. Metallurgical Transactions A, 1991, 22(5): 1049-1058.

[27] C Xiang. Alloy Steels. Beijing: Metallurgy Press, 1999. (in Chinese)

[28] D. Lonsdale, P.E.J. Flewitt, D, Lonsdale, P, et al. The role of grain size on the ductile-brittle transition of a 2.25 Pct Cr-1 Pct Mo steel. Metallurgical Transactions A, 1978, 9: 1619-1623.

[29] T. Hanamura, F. Yin, K. Nagai. Ductile-brittle transition temperature of ultrafine ferrite/cementite microstructure in a low carbon steel controlled by effective grain size. ISIJ International, 2004, 44(3): 610617.

[30] S.H. Kim, W.S. Ryn, I.H. Kuk, Nucl. Eng. Technol. 31 (1999) 561-571.

[31] E.A. Little, D.R. Harries, F.B. Pickering, in: S.F. Pugh, E.A. Little (Eds.), Proc. Int. Conf. Ferritic Steels for Fast Reactor Steam Generator, British Nuclear Energy Society, London, 1978, pp. 136-144. 
[32] A.H. Cai, Y. Zhou, J.Y. Tan, Y. Luo, T.L. Li, M. Chen, W.K. An, Optimization of composition of heattreated chromium white cast iron casting by phosphate graphite mold. Journal of Alloys and Compound, 2008, 466: 273-280.

[33] R.C. Fan, M. Gao, Y.C. Ma, X.D. Zha, X.C. Hao, K. Liu. Effects of Heat Treatment and Nitrogen on Microstructure and Mechanical Properties of Cr12NiMo Martensitic Stainless Steel. Journal of Materials Science Technology, 2012, 28: 1059-1066.

[34] S.J. Kim, Y.G. Cho, C.S. Oh, D.E. Kim, M.B. Moon, H.N. Han. Development of a dual phase steel using orthogonal design method. Materials and Design, 2009, 30: 1251-1257.

[35] Y Li, Q Huang, Y Wu, et al. Mechanical properties and microstructures of China low activation martensitic steel compared with JLF-1. Journal of Nuclear Materials, 2007, 367-370: 117-121.

[36] A Moitra, P Parameswaran, P R Sreenivasan, et al. A toughness study of the weld heat-affected zone of a $9 \mathrm{Cr}-1$ Mo steel. Materials Characterization, 2002, 48: 55-61.

[37] K H Hartman, H D Kunze, L W Meyer. Shock Waves and High-Strain-Rate Phenomena in Metals. Boston, MA: Springer, 1980.

[38] C Y Gao, L C Zhang. A constitutive model for dynamic plasticity of FCC metals. Materials Science and Engneering: A, 2010, 527: 3138-3143.

[39] C Pandey, A Giri, M M Mahapatra. Evolution of phases in P91 steel in various heat treatment conditions and their effect on microstructure stability and mechanical properties. Materials Science and Engneering: A, 2016, 664: 58-74.

[40] H Sakasegawa, T Hirose, A Kohyama, et al. Effects of precipitation morphology on toughness of reduced activation ferritic/martensitic steels. Journal of Nuclear Materials, 2002, 307-311: 490-494.

[41] S T Rolfe, J M Barsom. Fracture and fatigue control in structures, Application of Fracture Mechanics, Upper Saddle River NJ: Prentice-hall, Inc., 1977.

[42] G T Hahn, M F Kanninen, A R Rosenfield. Fracture Toughness of Materials. Annual Review of Materials Research, 1972, 2(1): 381-404.

[1] Schaefer, A. O. Symposium on structural materials for service at elevated temperatures in nuclear power generation, American Society of Mechanical Engineering winter annual meeting, Houston, USA, November 30-Desember 3, 1975: 375-385.

[2] A Chatterjee, D Chakrabarti, A Moitra, et al. Effect of normalization temperatures on ductile-brittle transition temperature of a modified $9 \mathrm{Cr}-1$ Mo steel. Materials Science and Engneering: A, 2014, A618: 219-231. 
[3] R L Klueh, A T Nelson. Ferritic/martensitic steels for next-generation reactors. Journal of Nuclear Materials, 2007, 371: 37-52.

[4] B N Singh, J H Evans. Significant differences in defect accumulation behaviour between fcc and bcc crystals under cascade damage conditions. Journal of Nuclear Materials, 1995,226: 277-285.

[5] B Raj, S Saroja, K Laha, et al. Methods to overcome embrittlement problem in 9Cr-1Mo ferritic steel and its weldment. Journal of Materials Science, 2009, 44: 2239-2246.

[6] F Masuyama. History of power plants and progress in heat resistant steels. ISIJ International, 2001, 41: 612-625.

[7] R L Klueh. Elevated emperature ferrtic and martensitic steels and their application to future nuclear reactors. Internatonal Materials Reviews, 2005, 50: 287-310.

[8] R Viswanathan, W Bakker. Materials for ultrasupercritical coal power plants-boiler materials: Part 1. Journal of Materials Engineering and Performance, 2001, 10: 81-95.

[9] R L Klueh, D J Alexander. Impact Behavior of 9Cr-1MoVNb and 12Cr-1MoVW steels Irradiated in HFIR. Journal of Nuclear Materials, 1991, 179-181: 733-736.

[10] C Wassilew, K Ehrlich. Effect of neutron irradiation on the dynamic fracture toughness behavior of the $12 \%$ Cr steel MANET-I investigated using subsize V-notch specimens. Journal of Nuclear Materials, 1992, 191-194: 850-854.

[11] Y Dai, P Marmy. Charpy impact tests on martensitic/ferritic steels after irradiation in SINQ target-3. Journal of Nuclear Materials, 2005, 343(1-3): 247-252.

[12] R L Klueh, J J Kai, D J Alexander. Microstructure-mechanical properties correlation of irradiated conventional and reduced-activation martensitic steels. Journal of Nuclear Materials, 1995, 225: 175-186.

[13] D S Gelles. Microstructural examination of commercial ferritic alloys at $200 \mathrm{dpa}$. Journal of Nuclear Materials, 1996, 233(1): 293-298.

[14] C Y Yang, Y K Luam, D Z Li, et al.. Effects of rare earth elements on inclusions and impact toughness of high-carbon chromium bearing steel. Journal of Materials Science Technology, 2019, 35: 1298-1308.

[15] Q Y Huang. Development status of CLAM steel for fusion application. Journal of Nuclear Materials, 2014, 455: 649-654.

[16] P Jung, H Klein. Segregation in DIN 1.4914 martensitic stainless steel under proton irradiation. Journal of Nuclear Materials, 1991, 182: 1-5.

[17] T. Watanabe, S. Tsurekawa. Toughening of brittle materials by grain boundary engineering. Materials Science and Engneering: A, 2004, 387-389: 447-455. 
[18] S.A. Bashu, K. Singh, M.S. Rawat. Effect of heat treatment on mechanical properties and fracture behaviour of a 12CrMoV steel. Materials Science and Engneering: A, 1990, 127: 7-15.

[19] T. Karthikeyan, V.T. Paul, S. Saroja, A. Moitra, G. Sasikala, M. Vijayalakshmi. Grain refinement to improve impact toughness in $9 \mathrm{Cr}-1 \mathrm{Mo}$ steel through a double austenitization treatment. Journal of Nuclear Materials, 2011, 419: 256-262.

[20] A. Chatterjee, A. Moitra, A.K. Bhaduri, D. Chakrabarti, R. Mitra, Effect of Heat Treatment on DuctileBrittle Transition Behaviour of 9Cr-1 Mo Steel. Procedia Engineering, 2014, 86: 287-294.

[21] J.B. Zhang, F. Liu, D. Fan, Z.Y. Zhen. Effect of Heat Treatment on Delta-ferritie and Impact Toughness of P91 Heat-resistant Steel. Transactions of Materials and Heat Treatment, 2017, 38: 108-113. (in Chinese)

[22] Chinese National Standard Committee. GB/T 5310-2008, Seamless steel tubes and pipes for high pressure boiler. Beijing: Standards Press of China, 2008. (in Chinese)

[23] R L Klueh., N Hashimoto, R F Buck et al. A potential new ferritic/martensitic steel for fusion applications. Journal of Nuclear Materials, 2000,283-287:697-701.

[24] N.Z. Gutiérrez, H. De Cicco, J. Marrero, C.A. Danón, M.I. Luppo. Evolution of precipitated phases during prolonged tempering in a $9 \% \mathrm{Cr} 1 \% \mathrm{MoVNb}$ ferritic-martensitic steel: Influence on creep performance. Materials Science and Engneering: A, 2011, 528: 4019-4029.

[25] C.X. Liu, D.T. Zhang, Y.C. Liu, Q. Wang, Z.S. Yan, Investigation on the precipitation behavior of M3C phase in T91 ferritic steels. Nuclear Engineering and Design, 2011, 241: 2411-2415.

[26] W.B. Jones, C.R. Hills, D.H. Polonis, Microstructural evolution of modified 9Cr-1Mo steel. Metallurgical Transactions A, 1991, 22(5): 1049-1058.

[27] C Xiang. Alloy Steels. Beijing: Metallurgy Press, 1999. (in Chinese)

[28] D. Lonsdale, P.E.J. Flewitt, D, Lonsdale, P, et al. The role of grain size on the ductile-brittle transition of a 2.25 Pct Cr-1 Pct Mo steel. Metallurgical Transactions A, 1978, 9: 1619-1623.

[29] T. Hanamura, F. Yin, K. Nagai. Ductile-brittle transition temperature of ultrafine ferrite/cementite microstructure in a low carbon steel controlled by effective grain size. ISIJ International, 2004, 44(3): 610617.

[30] S.H. Kim, W.S. Ryn, I.H. Kuk, Nucl. Eng. Technol. 31 (1999) 561-571.

[31] E.A. Little, D.R. Harries, F.B. Pickering, in: S.F. Pugh, E.A. Little (Eds.), Proc. Int. Conf. Ferritic Steels for Fast Reactor Steam Generator, British Nuclear Energy Society, London, 1978, pp. 136-144. 
[32] A.H. Cai, Y. Zhou, J.Y. Tan, Y. Luo, T.L. Li, M. Chen, W.K. An, Optimization of composition of heattreated chromium white cast iron casting by phosphate graphite mold. Journal of Alloys and Compound, 2008, 466: 273-280.

[33] R.C. Fan, M. Gao, Y.C. Ma, X.D. Zha, X.C. Hao, K. Liu. Effects of Heat Treatment and Nitrogen on Microstructure and Mechanical Properties of $\mathrm{Cr} 12 \mathrm{NiMo}$ Martensitic Stainless Steel. Journal of Materials Science Technology, 2012, 28: 1059-1066.

[34] S.J. Kim, Y.G. Cho, C.S. Oh, D.E. Kim, M.B. Moon, H.N. Han. Development of a dual phase steel using orthogonal design method. Materials and Design, 2009, 30: 1251-1257.

[35] Y Li, Q Huang, Y Wu, et al. Mechanical properties and microstructures of China low activation martensitic steel compared with JLF-1. Journal of Nuclear Materials, 2007, 367-370: 117-121.

[36] A Moitra, P Parameswaran, P R Sreenivasan, et al. A toughness study of the weld heat-affected zone of a $9 \mathrm{Cr}-1$ Mo steel. Materials Characterization, 2002, 48: 55-61.

[37] K H Hartman, H D Kunze, L W Meyer. Shock Waves and High-Strain-Rate Phenomena in Metals. Boston, MA: Springer, 1980.

[38] C Y Gao, L C Zhang. A constitutive model for dynamic plasticity of FCC metals. Materials Science and Engneering: A, 2010, 527: 3138-3143.

[39] C Pandey, A Giri, M M Mahapatra. Evolution of phases in P91 steel in various heat treatment conditions and their effect on microstructure stability and mechanical properties. Materials Science and Engneering: A, 2016, 664: 58-74.

[40] H Sakasegawa, T Hirose, A Kohyama, et al. Effects of precipitation morphology on toughness of reduced activation ferritic/martensitic steels. Journal of Nuclear Materials, 2002, 307-311: 490-494.

[41] S T Rolfe, J M Barsom. Fracture and fatigue control in structures, Application of Fracture Mechanics, Upper Saddle River NJ: Prentice-hall, Inc., 1977.

[42] G T Hahn, M F Kanninen, A R Rosenfield. Fracture Toughness of Materials. Annual Review of Materials Research, 1972, 2(1): 381-404.

\section{Figures}




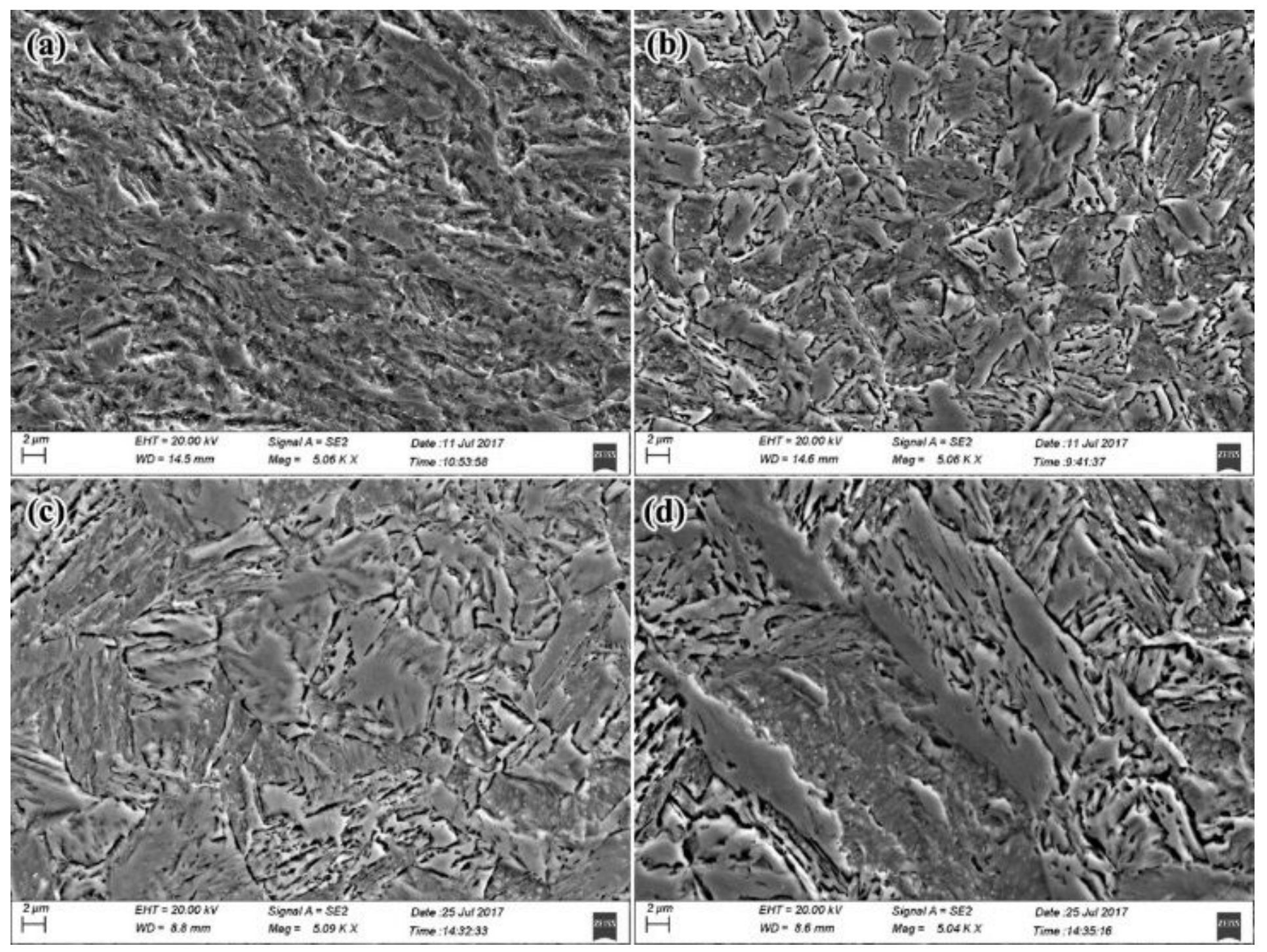

Figure 1

SEM images of GN9 steel at different conditions: (a) hot-rolled, (b) $1000^{\circ} \mathrm{C}+\mathrm{AC}$, (c) $1050^{\circ} \mathrm{C}+\mathrm{AC}$, (d) 1080 ${ }^{\circ} \mathrm{C}+\mathrm{AC}$ 


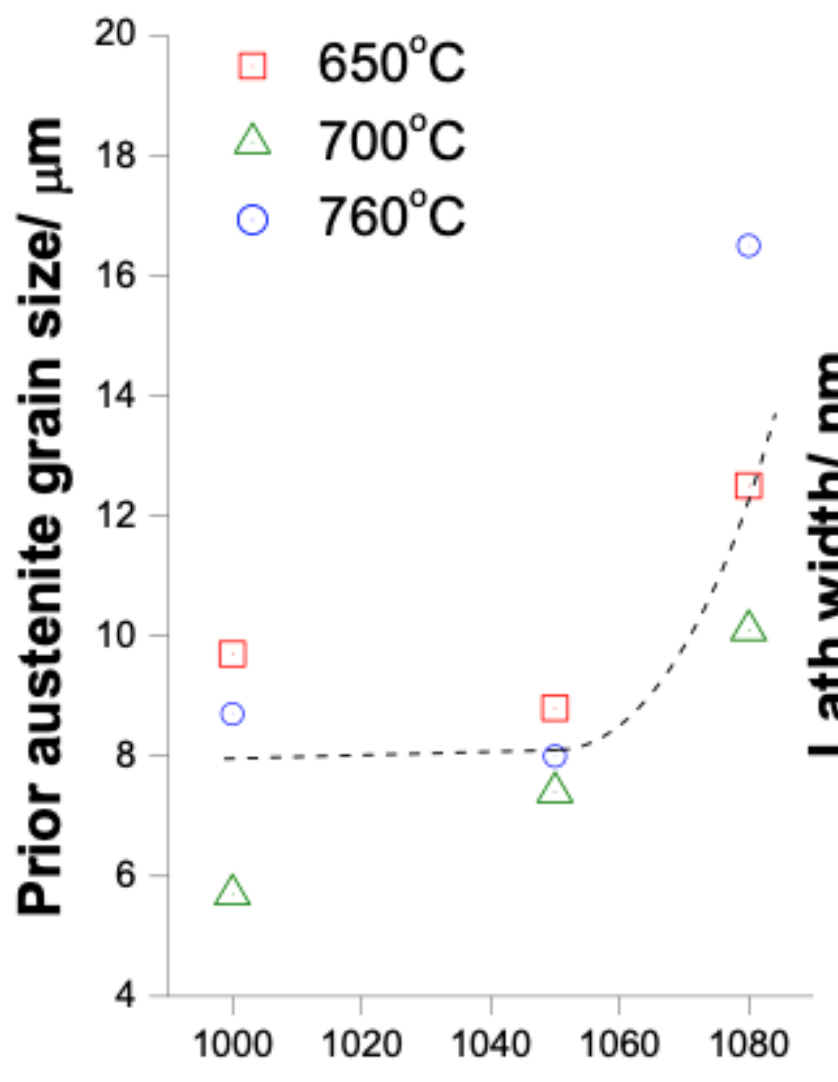

Austenization temperature $/{ }^{\circ} \mathrm{C}$

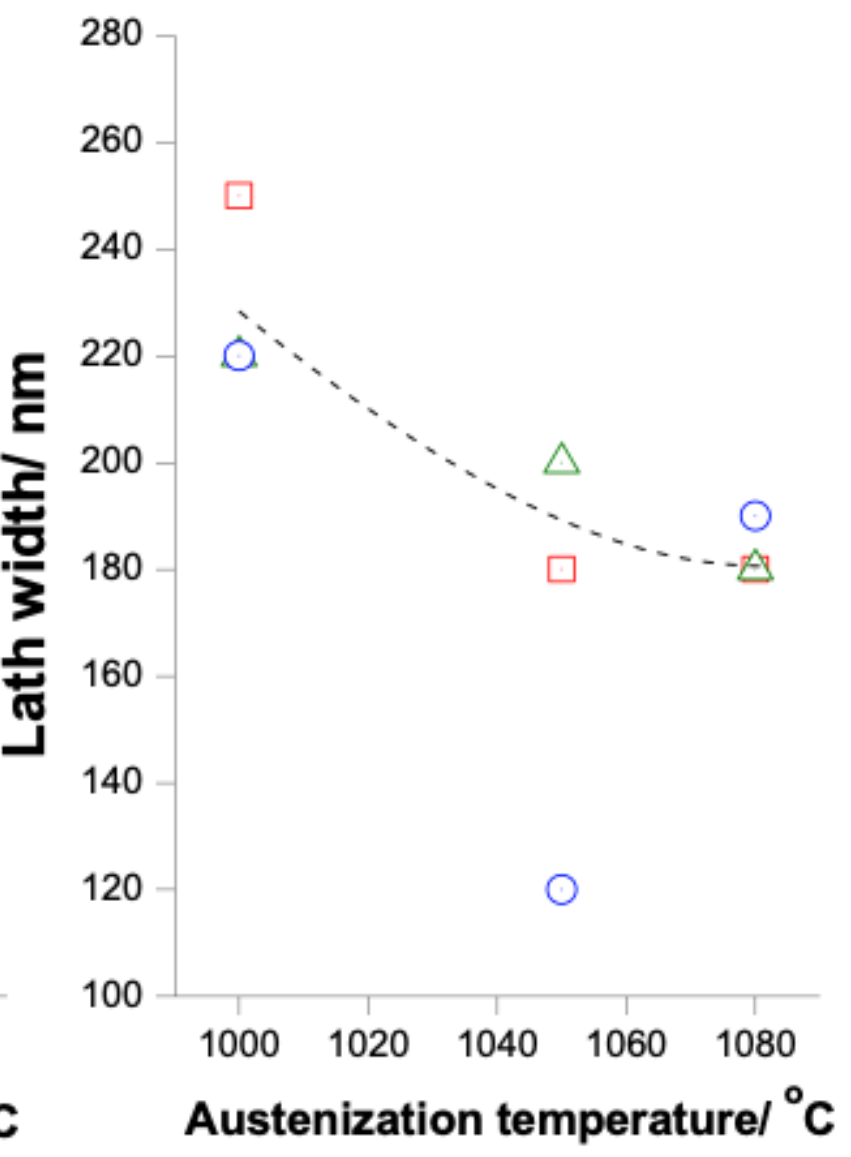

Figure 2

Prior austenite grain size of GN9 steel specimens at different heat treatment conditions 


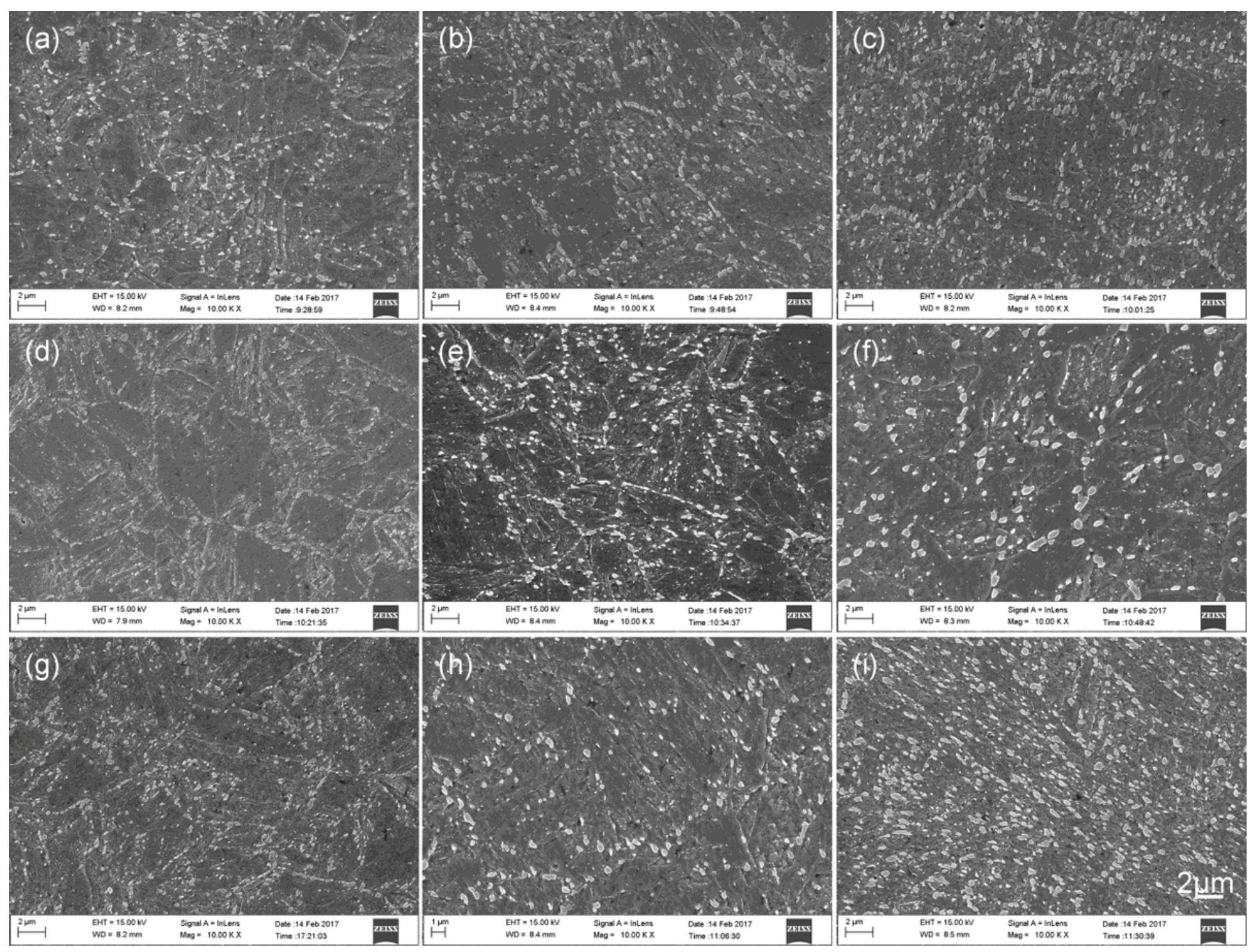

Figure 3

SEM images of carbide distribution in GN9 steel specimens at different heat treatment conditions: (a) OW, (b) 00, (c) 0A, (d) 50, (e) 5A, (f) 5W, (g) 8A, (h) 8W, (i) 80 


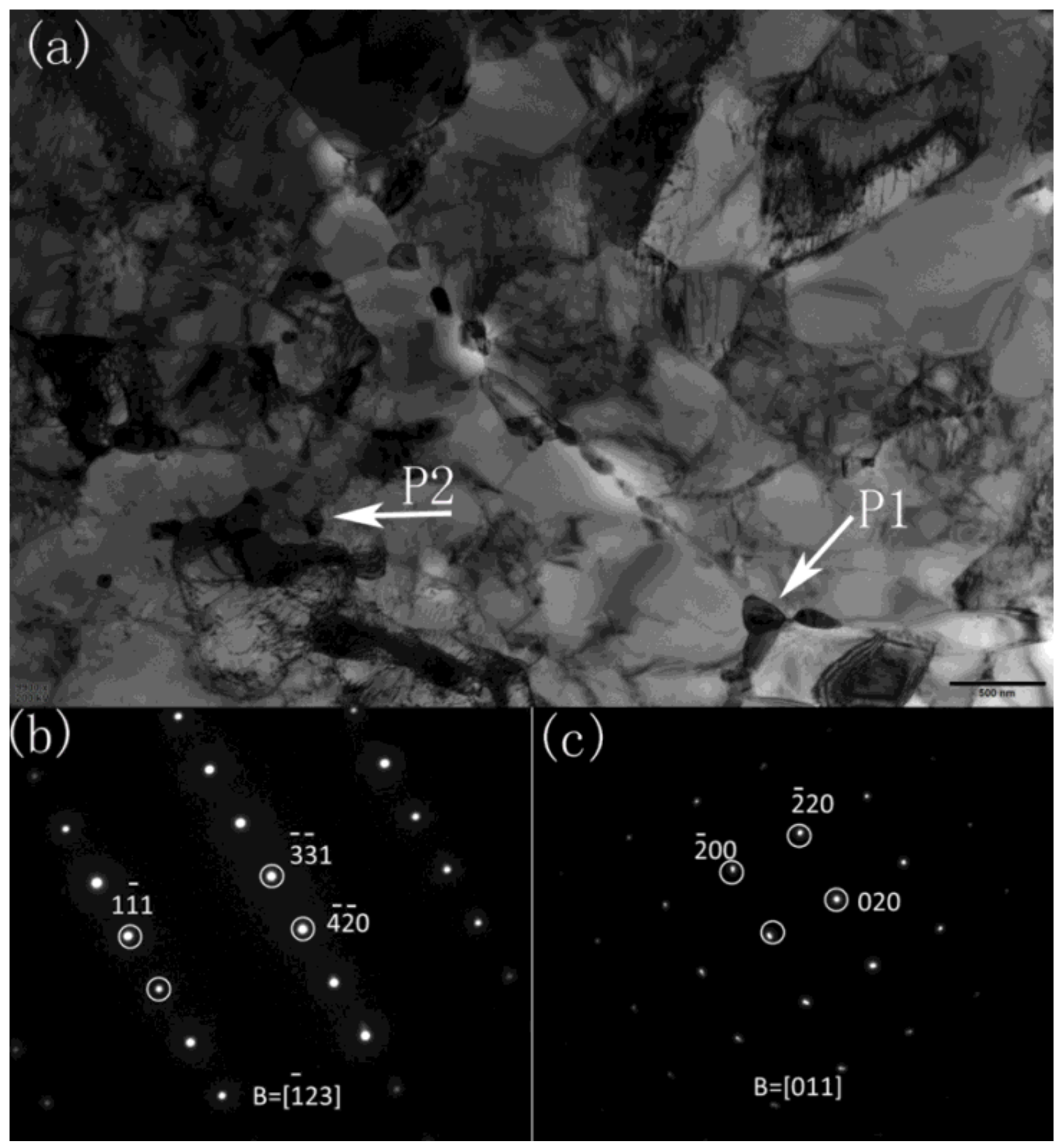

\section{Figure 4}

TEM micrographs of GN9 steel in OA condition: (a) tempered martensite laths, (b) M23C6 SAED of P1 in (a), and (c) MX SAED of P2 in (a) 


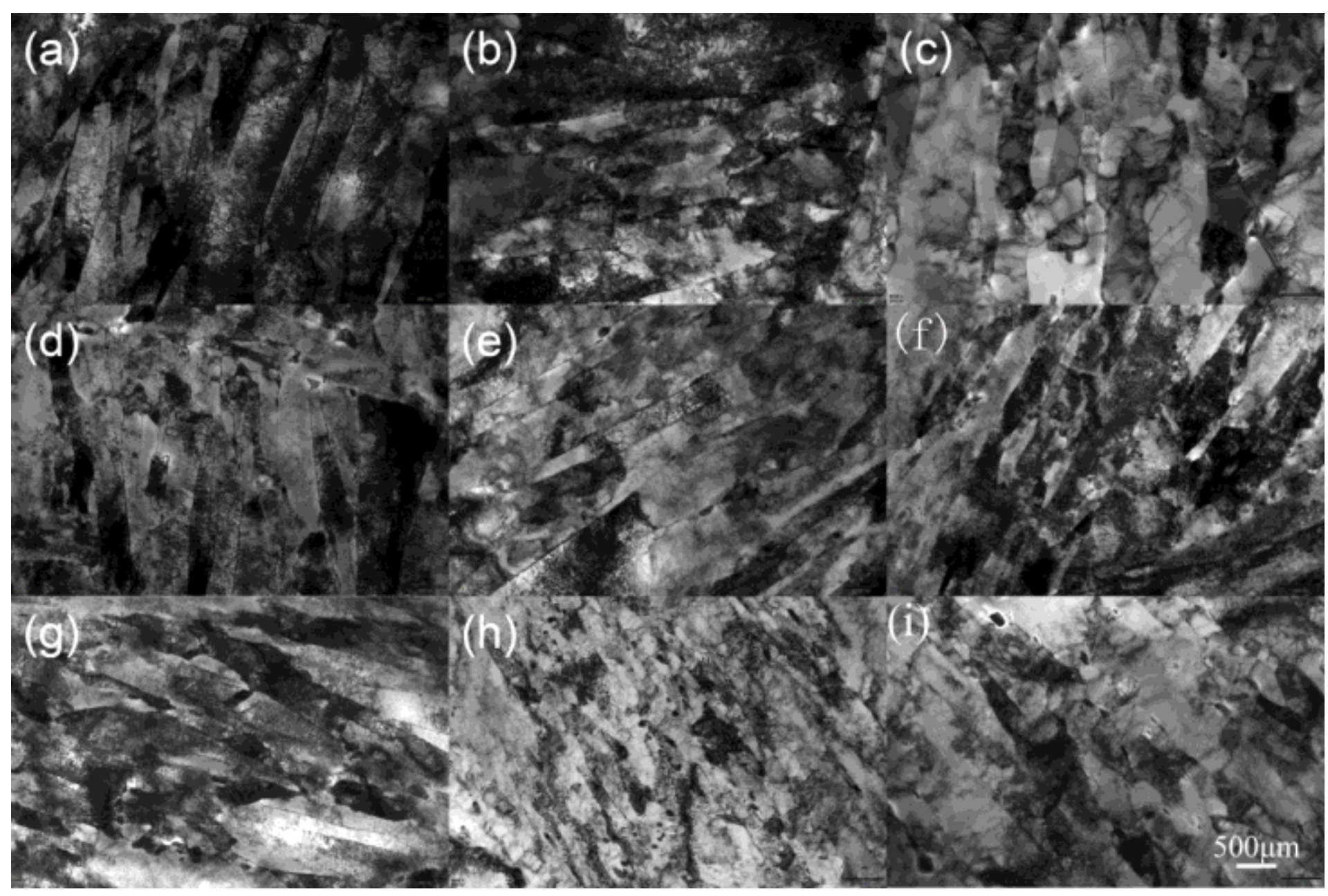

Figure 5

TEM micrographs of GN9 steel at different heat treatment conditions: (a) 0W, (b) 00, (c) 0A, (d) 50, (e) 5W, (f) $5 \mathrm{~A},(\mathrm{~g}) 8 \mathrm{~A}$, (h) $8 \mathrm{~W}$, (i) 80 

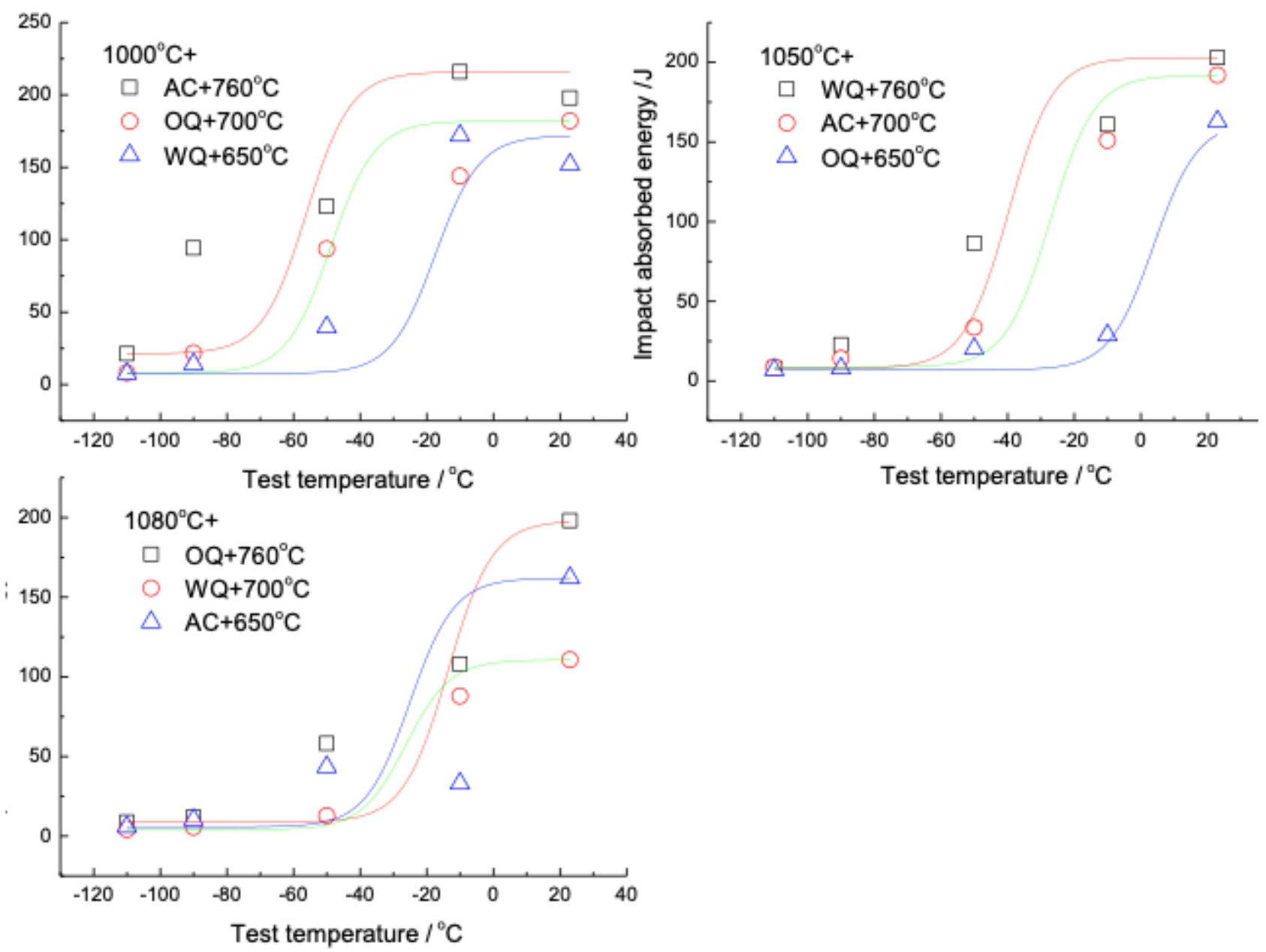

\section{Figure 6}

Correlation of Charpy impact energy, test temperature and heat treatment for GN9 steel specimens 


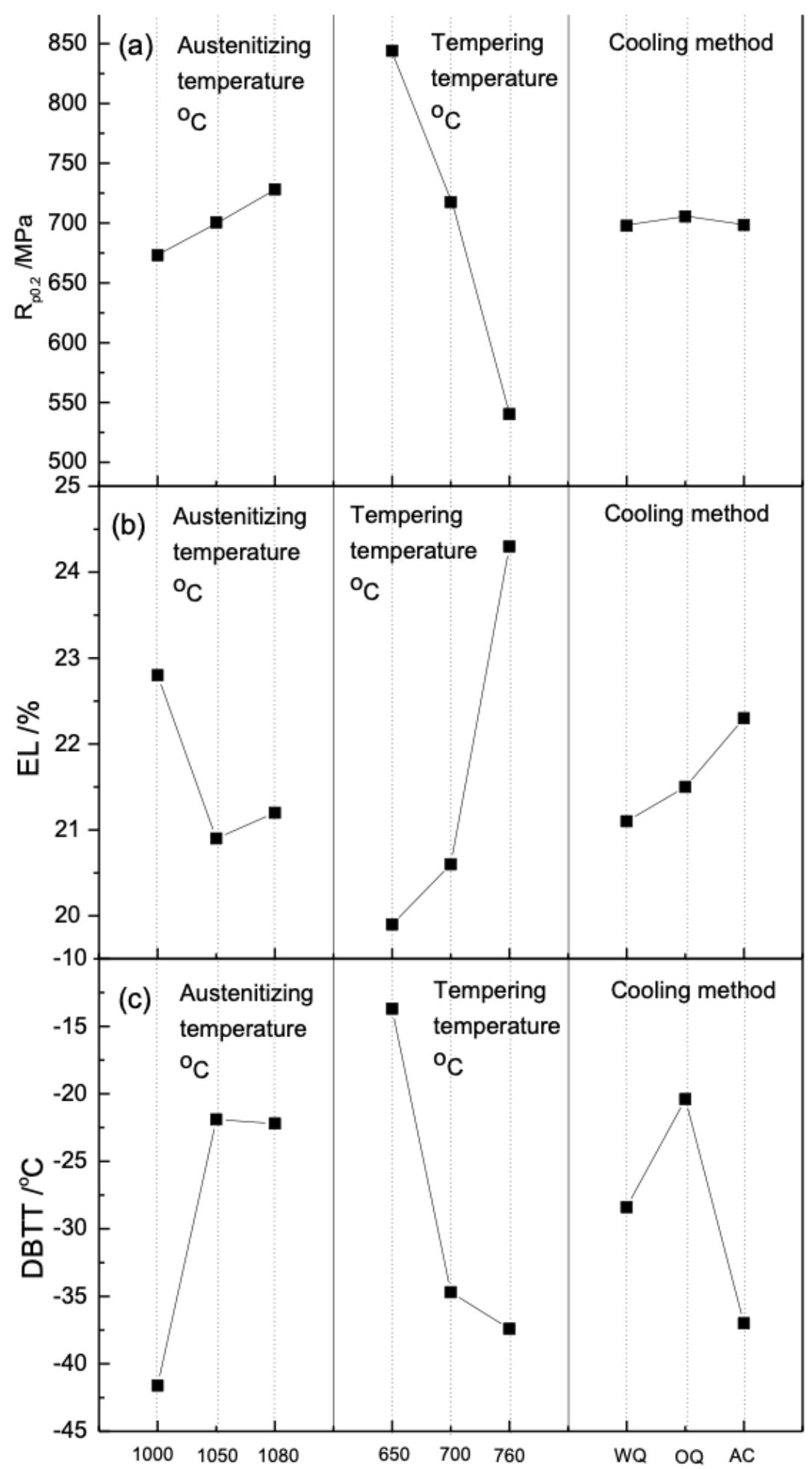

Figure 7

Effects of austenitizing temperature, tempering temperature, cooling method on (a) yield strength, (b) elongation and (c) ductile-to-brittle transition temperature 

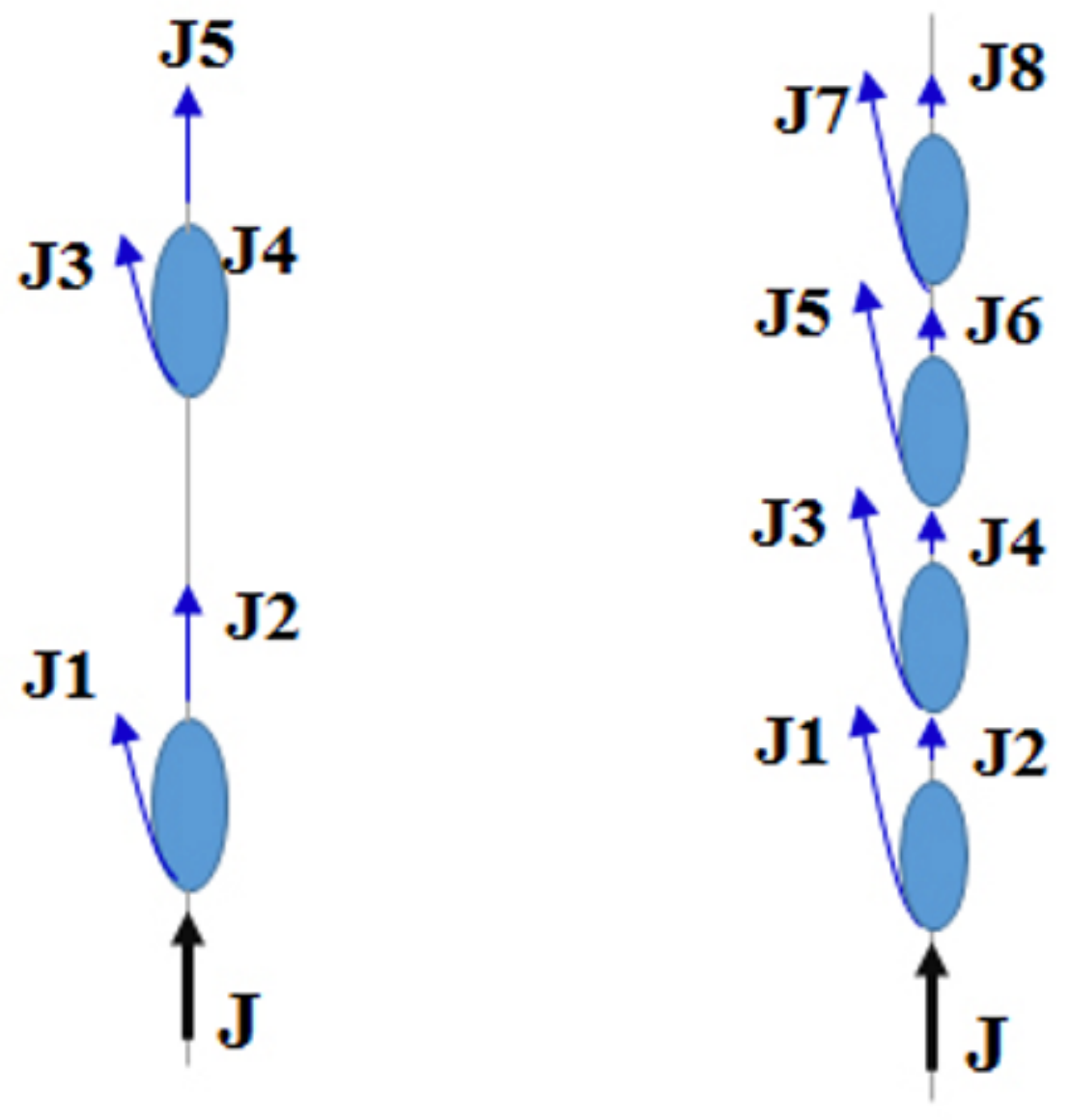

\section{$K v=\mathrm{J} 1+\mathrm{J} 3$}

$K v=\mathrm{J} 1+\mathrm{J} 3+\mathrm{J} 5+\mathrm{J} 7$

(a) discrete carbide

(b) dense carbide

Figure 8

Mechanism of carbide effects on Charpy impact toughness of GN9 steel 